\title{
A minimum of roughage and a maximum of starch - necessary benchmarks for equine diets
}

\author{
Manfred Coenen und Ingrid Vervuert \\ Institut für Tierernährung, Ernährungsschäden und Diätetik, Leipzih
}

\begin{abstract}
Summary
The rations for modern leisure or performance horses are hardly influenced by the tradition of feeding horses doing farm work or serving in public infrastructure and industry as hard working animals. Typically roughage is limited and concentrates are dosed to balance the caloric needs. However, limitations in roughage are in conflict with the time budget of the horse today as it is not full time exercised. The actual roughage management often neglect the perspectives of this feed to contribute to energy and nutrient intake even in performance horses. Data on diets for 3-day eventers confirm the suitability of rations high in roughage. The huge impact of roughage on saliva production, speed of feed intake and - possibly the most important link - on behaviour requires to define this part of equine diets by the recommendation of feeding daily min $15 \mathrm{~g}$ roughage/ $\mathrm{kg}$ body weight (defined as as feed of $88 \%$ dry matter). This amount will even at low feeding levels cover the caloric needs for maintenance. High starch intake changes the bacterial community in the entire digestion tract. This is in principle accepted as a risk factor for gut health. Consequently a limitation in starch intake is an essential factor in safe rationing. But two further factor need to be included for deriving a starch limitation. Glucose as the product of starch digestion induces an insulin response. In case of high starch intake this response is enforced and characterized by a persistency of insulin activities in blood distinctly above base levels, a situation which is in conflict to the preferential status of a horse prior exercise. Additionally epidemiological data identify high starch intake a a risk factor for the development of gastric lesions/ulcers. These facts are recognized by the recommendation to limit starch intake per meal at $1 \mathrm{~g} / \mathrm{kg}$ body weight.
\end{abstract}

Keywords: Horse, starch, roughage, starch, requirement, gut health, ration

\section{Ein Minimum an Raufutter und ein Maximum an Stärke - notwendige Limitierungen in Rationen für Pferde}

Die Nutzung des Pferdes als Arbeitstier in der Landwirtschaft aber auch für das Transportwesen und die Industrie bedingte eine erhebliche Einschränkung der zur Futteraufnahme verfügbaren Zeit, war andererseits aber von hoher Intensität. Die allgemein konzentratreichen Rationen erreichten beispielesweise bei Pferden die im öffentlichen Nahverkehr eingesetzł waren, rund 170 MJ verdauliche Energie (DE)/Tag., entsprechend dem Bedarf für schwere oder sehr schwere Arbeit. Raufutter, meist Heu-Strohgemenge, war nicht beliebig verfügbar, was auch durch die Nutzung von Laubheu als Ersatz von Heu oder Stroh belegt ist. Das moderne Leistungspferd erhält Rationen von 10-13 kg/Tag mit Konzentratanteilen von 20 bis mehr als 50 \%. Die Energiezuteilung variiert größenordnungsmäßig um 130 MJ DE/Tag. Raufutter wird allgemein begrenzt eingesetzt. Dies ist insofern bemerkenswert als die Art und Intensität der Arbeitsbelastung des Sportpferdes die Raufuttermenge nicht limitiert, was Daten zur Fütterungspraxis bei Vielseitigkeitspferden belegen. Dennoch ist die Fütterung des heutigen Sportpferdes an der des Arbeitpferdes alter Prägung orientiert, obwohl die Nutzungsdauer/Tag wie auch die Beanspruchung selbst i.d.R. niedriger sind. Zusätzlich werden die Perspektiven des Raufutters, zur Energie- und Nährstoffversorgung des Sportpferdes beizutragen, unterbewertet. Unabhängig hiervon muss aber Raufutter im Komplex Ernährung und Verhalten gewürdigt werden. Die Daver der Futteraufnahme (=Beschäftigung), die Intensität der Speichelbildung bei Raufutterverzehr stehen für Effekte jenseits der Energiezufuhr. Bei Würdigung der physiologischen Bedingungen und des Anforderungsprofils heutiger Pferde ist es zwingend, einer Begrenzung des Raufutters zu entgegen; die Empfehlung zur Raufutterversorgung von Pferden lautet demnach mind. $15 \mathrm{~g} / \mathrm{kg}$ Körpermasse je Tag (definiert für Raufutter mit 88 \% Trockenmasse). Stärkereiche Rationen sind mit Blick auf die Fermentationsbedingungen im Magen/Darmtrakt einer kritischen Wertung unterzogen. Tatsächlich wird eine umfassende Veränderung des bakteriellen Profils im gesamten Verdauungskanal bereits bei typischen Konzentratmengen beobachtet. Vor allem aber die Insulinreaktion auf die der Stärkeaufnahme dosisabhängig folgende Glukoseabsorption sowie die Häufigkeit von Schäden der Magenschleimhaut geben Anlass, die Stärkeaufnahme zu limitieren. Experimentelle und epidemiologische Daten zu diesen Zusammenhängen führen zu der Empfehlung, die Stärkeaufnahme je Mahlzeit auf $1 \mathrm{~g} / \mathrm{kg}$ Körpermasse zu begrenzen.

Schlüsselwörter: Pferd, Raufutter, Stärke, Bedarf, Verträglichkeit, Ration

\section{Introduction}

Energy and nutrient requirements of horses are defined by the status of the animal; maintenance, pregnancy, lactation, work or growth. The crucial role of horses in the late industrial revolution, up to the middle of the last century for farm work and for transport in the fast growing urban areas as well as in the industries like mining, initiated scientific work on their energy, protein and mineral requirements. However, knowing how to feed the horse goes beyond just consideration of energy and nutrient supply. The responses of horses to diet are a complex of gut health, endocrine interaction and behaviour.
Recent studies show an impact of fibre and starch intake on this complex and thus these dietary elements need to be defined to ensure safe horse nutrition.

\section{Hintergrund}

Depending on the season a daily workload continued for 7 $10 \mathrm{~h}$ requiring a feed intake at about $4 \%$ of body weight (Simms 1927). The amount of feeds exceeded $10 \mathrm{~kg}$ per day and the rations included $40-60 \%$ concentrates, mainly grain (Anonym 1908, Harris 1998). Report on horses used in 
public transportation (no cold blooded horses) describe daily rations of $10-19 \mathrm{~kg}$ with $26-70 \%$ grain, $21-67 \%$ roughage, up to $21 \%$ legumes (Lavalard 1888). The feeding level corresponded to that of hard work evidenced by a daily energy intake of about $170 \mathrm{MJ}$ digestible energy (DE). One objective of feeding trials in those times was to minimise the cost of feeding working animals. The fact that leaf hay was intensively used in horse feeding (Slotte 2001) reflects the shortage in roughage and the need for other resources.

The elite performance horses today are fed $10-13 \mathrm{~kg} / \mathrm{d}$; the rations contain between 20 and $50+\%$ concentrates (Ralston 1988, Southwood et al. 1993, Southwood et al. 1993, Richards et al. 2006, Vervuert and Coenen 2008). The energy allowance is about $130 \mathrm{MJ} D E / \mathrm{d}$. It is evident that roughage-feeding is limited and concentrates are used to meet the expected energy requirement. In contrast, the nature and intensity of exercise does not define an upper limit to roughage inclusion as shown by those diets (8.6-9,3 kg roughage/d plus access to pasture) fed to 3-day-eventers (Burk and Williams 2008). Regardless total energy requirements, horse diets are commonly characterized by including only limited amounts of roughage. Furthermore, the majority of these horses are only being used for low intensity exercise. A Swiss survey showed that an average leisure horse is used 4,5 h per week (Bachmann and Stauffacher 2002).

Traditions in horse feeding have originated from their intensive use as working animals and modern horse diets that neglect caloric needs and the role of roughage for the horse's wellbeing reflect this.

\section{Reasons to define a minimum of roughage}

Fibrous feeds are required for safe gut function for a hindgut fermenter like the horse. The majority of energy is derived from hindgut fermentation via acetate and propionate. Sophisticated work with catheterized horses fed by hay alone or a hayconcentrate diet showed the high capacity of a hay diet to fuel energy metabolism in the muscle (Pethick et al. 1993, Southwood et al. 1993). Moreover, the feeding value of roughage is underestimated. The stage of grass growth determines the carbohydrate profile; the increase in lignin is accompanied by a sharp decline in digestible energy supply within a few weeks (Ragnarsson and Lindberg 2008). Roughage inclusion in the diet can be maximised/regulated by managing its feeding value by choosing harvest time in relation to intended use. More roughage in the diet will not necessarily limit energy intake but will address behavioural issues. Feeding management can create a high impact on behaviour particular at low fibre intakes and reduced feeding times. Behavioural problems are recognized as a major problem in modern horse husbandry (Boyd 1986, Bachmann et al. 2003, Henderson 2007, Motch et al. 2007, Parker et al. 2008, Minero and Canali 2009). As roughage intake contributes most to the portion of the daily time budget covered by feed intake, it is logical to define roughages a contributor to both energy and behavioural needs. The total time a horse spends eating is between 13-15 h per day (Meyer and Coenen 2002). Differences in the rate of intake of different feeds are well known and can be summarized as follows: concentrates $10 \mathrm{~min} / \mathrm{kg}$, roughage $45 \mathrm{~min} / \mathrm{kg}$. Recent studies have shown how roughage can affect rate of intake (Brüssow 2006 and 2008, Brokner et al. 2008, Vervuert et al. 2009). The major outcomes are that roughage in admixture with concentrate is not as effective at slowing down rate of intake but that roughage, freely available overnight, lowers feed intake rate when fed a meal in the morning. As saliva is only produced during chewing and chewing frequency is fairly constant at $\sim 1.5-2$ chews/sec it is evident that increasing chewing time by feeding roughage is the most important factor that defines saliva production and thus, gastric function. The amount of saliva per $100 \mathrm{~g}$ feed increases in dependence on time for intake: saliva/100 g feed $=9.4+49.4^{*}$ Min./100 g feed. (Meyer et al. 1985).

The physiological interaction between feeding, behaviour and gastric function is supported by recommending a minimum roughage supply of $15 \mathrm{~g} / \mathrm{kg}$ body weight (BW) per day (defined as roughage with $88 \%$ dry matter). The rationale for choosing this particular level is based on the daily maintenance energy requirement of about $0.6 \mathrm{MJ} \mathrm{DE} / \mathrm{kg} \mathrm{BW}$. This quantity of roughage, irrespective of quality, will ensure an adequate energy supply for maintenance whilst high quality of roughage will also meet the needs for moderate exercise. Another consideration is that about $40-50 \%$ of a horses' time is spent eating roughage under natural conditions. If horses are overweight it may be necessary to modify this feeding level for dietetic reasons.

\section{Reasons to define a maximum of starch}

If a $500 \mathrm{~kg}$ horse is fed $15 \mathrm{~g}$ roughage $(9 \mathrm{MJ} / \mathrm{kg}) / \mathrm{kg} \mathrm{BW} /$ day it will need additionally about $3-4 \mathrm{~kg}$ oats to cover the caloric needs for moderate exercise ( $110 \mathrm{MJ} \mathrm{DE} / \mathrm{d})$. Thus, the starch intake will be between 2.7 and $3.6 \mathrm{~g} / \mathrm{kg} \mathrm{BW}$ if fed as one meal At this level of starch intake there is a response by the microflora in the entire gastro-intestinal tract (de Fombelle 2001, de Fombelle et al. 2003); the major effect is an increase in lactic acid producing bacteria and a decrease in both lactic acid consuming organisms and cellulolytic bacteria. The low fibre, high starch effect on the gut is reflected in low faecal $\mathrm{pH}$, a rough indicator of a depressed fermentation of non starch carbohydrates (Zeyner 2004, Williamson et al. 2007). The horses' hindgut has a limited tolerance to the outcomes of starch fermentation. It is notable that a response to starch intake is initiated in the stomach demonstrated by a rapid increase in hydrogen exhalation that indicates precaecal microbial starch breakdown (Coenen et al. 2006). These aspects of digestive physiology are reasons for limiting starch intake. As the responses are related to the amount of starch entering the gut, it is necessary to define the safe amount of starch per meal.

The effect of starch on gut health is demonstrated by hindgut acidosis that follows excessive starch feeding excessive starch feeding (Williamson et al. 2007) and the unacceptable frequency of lesions of the gastric mucosa (Jonsson and Egenvall 2006, Bell et al. 2007, Reese and Andrews 2009). A recently published study indicates the risks of feeding $>2 \mathrm{~g}$ starch $/ \mathrm{kg}$ BW per day or even $>1 \mathrm{~g}$ starch $/ \mathrm{kg}$ BW per meal (Luthersson et al. 2009). The glucose and insulin responses to starch intake reflects the digestion end products of starch digestion in the small intestine as well as the endocrine response. This combined response depends on the botanical origin of the starch, cereal processing and quantitative intake (Vervuert et al. 2003, Vervuert et al. 2004, Vervuert et al. 2007, Vervuert et al. 2008, Vervuert et al. 2009). 
A starch intake above $1 \mathrm{~g} / \mathrm{kg}$ BW per meal produces a distinct insulin response in comparison to feeding $0.8 \mathrm{~g}$ starch $/ \mathrm{kg}$ BW per meal or less. The temporary hyperinsulinemic state and the persistency of high insulin activity in blood for more than $4 \mathrm{~h}$ after starch intake are in conflict with the required status of a horse ready to start exercise. In addition, consideration of the dietary starch -glucose absorption-insulin secretion interaction fits with the need to restrict starch intake in order to minimise orthopaedic disorders and to prevent insulin resistance developing. Consequently, accordingly to the current state of knowledge the maximum level of starch for horses is $1 \mathrm{~g} / \mathrm{kg} \mathrm{BW}$ per meal.

\section{References}

Anonym (1908). Animal Management. His majesty s staionary Office. Lodon, UK

Bachmann I., Audige L. and Stauffacher M. (2003) Risk factors associated with behavioural disorders of crib-biting, weaving and boxwalking in Swiss horses. Equine Vet. J. 35, 158-163

Bachmann I. and Stauffacher M. (2002) [Housing and use of horses in Switzerland: a representative analysis of the status quo]. Schweiz. Arch. Tierheilkd. 144, 331-347

Bell R. J., Kingston J. K., Mogg T. D. and Perkins N. R. (2007) The prevalence of gastric ulceration in racehorses in New Zealand. N. Z. Vet. J. 55, 13-18

Bochnia M. (2008) Einfluss der Fütterungsreihenfolge von Heu, Heuhäcksel und Mais auf die Futteraufnahme und Kauaktivität von Mais beim Pferd. Diss. Med. Vet. Leipzig

Boyd L. (1986) Behavior problems of equids in zoos. Vet. Clin. North. Am. Equine Pract. 2, 653-664.

Brokner C., Norgaard P. and Hansen H. H. (2008) Effect of feed type and essential oil product on equine chewing activity. J. Anim. Physiol. Anim. Nutr. (Berl) 92, 621-630.

Brüssow N. (2006) Effekte verschiedener Futtermittel und -bearbeitungsformen auf die Futteraufnahmedauer, die Kaufrequenz und die Kauintensität beim Pferd. Vet. Med. Diss. Hannover

Burk A. O. and Williams C. A. (2008) Feeding management practices and supplement use in top-level event horses. Comp. Ex. Phys. 5, 85-93

Coenen M., Mosseler A. and Vervuert I. (2006) Fermentative gases in breath indicate that inulin and starch start to be degraded by microbial fermentation in the stomach and small intestine of the horse in contrast to pectin and cellulose. J. Nutr. 136(7 Suppl), 2108S-2110S

Fombelle de A. (2001) Feeding and Microbial disorders in Horses: 1 Effects of an abrupt Incorporation of two Levels of Barley in a Hay Diet on microbial profile and activities. Equine Vet. Sci. 21, 439-445

Fombelle de A., Varloud M., Goachet A. G., Jacotot E., Philippeau C., Drogul C. and Julliand V. (2003) Characterization of the microbial and biochemical profile of the different segments of the digestive tract in the horses given two distinct diets. Animal Sci. 77, 293-304

Harris P. A. (1998) Developments in equine nutrition: comparing the beginning and end of this century. J. Nutr. 128(12 Suppl), 2698S27035

Henderson A. J. (2007) Don't fence me in: managing psychological well being for elite performance horses. J Appl. Anim. Welf. Sci. 10, 309-329

Jonsson H. and Egenvall A. (2006) Prevalence of gastric ulceration in Swedish Standardbreds in race training. Equine Vet. J. 38, 209-213

Lavalard E. (1888) Le Cheval dans ses Rapports avec I Économie rurale et les Industries de Transport. Paris, Librairie de Firmin-Didot et Cie

Luthersson N., Nielsen K. H., Harris P. and Parkin T. D. (2009) Risk factors associated with equine gastric ulceration syndrome (EGUS) in 201 horses in Denmark. Equine Vet. J. 41, 625-630

Meyer H. and Coenen M. (2002) Pferdefütterung. Berlin, Parey

Meyer H., Coenen M. and Probst D. (1985) Beiträge zur Verdauungsphysiologie 14. Mitteilung - Futtereinspeichelung und -passage im Kopfdarm des Pferdes. J. Anim. Physiol. Anim. Nutr. 56, 171-183
Minero M. and Canali E. (2009) Welfare issues of horses: an overview and practical recommendations. Italian J. Anim. Sci. 8, 219

Motch S. M., Harpster H. W., Ralston S., Ostiguy N. and Diehl N. K. (2007) A note on yearling horse ingestive and agonistic behaviours in three concentrate feeding systems. Applied Animal Behaviour Science 106, 167-172

Parker M., Goodwin D. and Redhead E. S. (2008) Survey of breeders' management of horses in Europe, North America and Australia: Comparison of factors associated with the development of abnormal behaviour. Applied Animal Behaviour Science 114, 206-215

Pethick D. W., Rose R. J., Bryden W. L. and Gooden J. M. (1993) Nutrient utilisation by the hindlimb of thoroughbred horses at rest. Equine Vet. J. 25, $41-44$

Ragnarsson S. and Lindberg J. E. (2008) Nutritional value of timothy haylage in Icelandic horses. Livestock Sci. 113, 202-208

Ralston S. L. (1988): Nutritional management of horses competing in $160 \mathrm{~km}$ races. Cornell Vet. 78, 53-61

Reese R. E. and Andrews F. M. (2009) Nutrition and dietary management of equine gastric ulcer syndrome. Vet. Clin. North. Am. Equine. Pract. 25, 79-92, vi-vii

Richards N., Hinch G. and Rowe J. (2006) The effect of current grain feeding practices on hindgut starch fermentation and acidosis in the Australian racing Thoroughbred. Aust. Vet. J. 84, 402-407

Simms A. (1927) Horse feeding tests. J. Anim. Sci. 133-134

Slotte H. (2001) Harvesting of leaf-hay shaped the Swedish landscape. Landscape Ecology 16, 691-702

Southwood L. L., Evans D. L., Bryden W. L. and Rose R. J. (1993) Feeding practices in thoroughbred and standardbred racehorse stables. Aust. Vet. J. 70, 184-185

Southwood L. L., Evans D. L., Bryden W. L. and Rose R. J. (1993) Nutrient intake of horses in thoroughbred and standardbred stables. Aust. Vet. J. 70, 164-168

Southwood L. L., Evans D. L., Hodgson D. R., Bryden W. L. and Rose R. J. (1993) The effect of roughage source on exercise performance and metabolism in thoroughbred horses. Cornell Vet. 83, 243-255

Vervuert I., Bothe C. and Coenen M. (2007) Glycaemic and insulinaemic responses to mechanical or thermal processed barley in horses. J. Anim. Physiol. Anim. Nutr. (Berl) 91, 263-268

Vervuert I., Brüssow N., Bochnia M., Hollands T., Cuddeford D. and Coenen M. (2009) Feeding strategies to modify the rate of feed intake and chewing activity. Proc. ESVCN-Conference 13, 47

Vervuert I. and Coenen M. (2008) Diets of elite performance horses in practice. unpublished

Vervuert I., Coenen M. and Bothe C. (2003) Effects of oat processing on the glycaemic and insulin responses in horses. J. Anim. Physiol. Anim. Nutr. (Berl) 87, 96-104

Vervuert I., Coenen M. and Bothe C. (2004) Effects of corn processing on the glycaemic and insulinaemic responses in horses. J. Anim. Physiol. Anim. Nutr. (Berl) 88., 348-355

Vervuert I., Voigt K., Hollands T., Cuddeford D. and Coenen M. (2008) Effects of processing barley on its digestion by horses. Vet. Rec. 162, 68

Vervuert I., Voigt K., Hollands T., Cuddeford D. and Coenen M. (2009) Effect of feeding increasing quantities of starch on glycaemic and insulinaemic responses in healthy horses. Vet. J. 182, 67-72

Williamson A., Rogers C. W. and Firth E. C. (2007) A survey of feeding, management and faecal $\mathrm{pH}$ of Thoroughbred racehorses in the North Island of New Zealand. N. Z. Vet. J. 55, 337-341

Zeyner A. (2004): Effects of hay intake and feeding sequence on variables in faeces and faecal water (dry matter, $\mathrm{pH}$ value, organic acids, ammonia, buffering capacity) of horses. J. Anim. Physiol. Anim. Nutr. (Berl) (88), 7-19.

Prof. Manfred Coenen

Institut für Tierernährung, Ernährungsschäden und Diätetik,

Gustav Kühn Str. 8

04159 Leipzig

coenen@vetmed.uni-leipzig.de 